\title{
New records of caridean shrimps, Lysmata ankeri and $L$. cf. intermedia, from southeast coast of Brazil
}

\author{
Samara De Paiva Barros-Alves ${ }^{1}$, Douglas Fernandes Rodrigues Alves ${ }^{1 *}$, Gustavo Luis Hirose ${ }^{1}$ and Valter José Cobo ${ }^{2}$
}

\begin{abstract}
Background: The genus Lysmata includes about 40 described species of which at least 12 species occur in the western Atlantic. The present study records the extension of the southern limit of distribution of two species of Lysmata to the coast of São Paulo.

Results: A total of 17 and two individual of Lysmata ankeri and Lysmata cf. intermedia were sampled, respectively. Lysmata ankeri were observed inhabiting crevices and natural burrows formed by rocks from 5 to about $15 \mathrm{~m}$ depth, while Lysmata cf. intermedia were found living under a large rocky plate from 8 meters depth.

Conclusions: These new records improve our knowledge about the geographical distribution of Lysmata ankeri and Lysmata cf. intermedia. The expansion of the geographical distribution of these species may be caused by two different mechanisms of larval dispersal, either natural or anthropogenic.
\end{abstract}

Keywords: Ballast water, Caridean shrimp, Lysmatidae

\section{Background}

The genus Lysmata Risso, 1816, belongs to the family Lysmatidae (Baeza, 2013) and includes about 40 described species (Chace, 1997; Rhyne \& Lin, 2006; Rhyne \& Anker, 2007; Baeza \& Anker, 2008; Anker et al., 2009; De Grave \& Fransen, 2011), of which at least 12 species occur in the western Atlantic (Chace, 1972; Rhyne \& Lin 2006).

Several studies in the last decade have provided additional information, describing new species and reviewing the geographic distribution of this genus (e.g., Wicksten, 2002a, 2002b; Rhyne \& Anker, 2007; Baeza \& Anker, 2008; Anker et al., 2009; Laubenheimer \& Rhyne, 2010). The present study records an extension of the southern limits of distribution of two species of shrimps, Lysmata ankeri Rhyne \& Lin, 2006 and Lysmata cf. intermedia (Kingsley, 1879), to the coast of São Paulo State, southeastern Brazil.

\footnotetext{
* Correspondence: douglas_biologo@yahoo.com.br

${ }^{1}$ Universidade Federal de Sergipe - UFS, Laboratório de Carcinologia, São

Cristóvão, Sergipe, Brazil

Full list of author information is available at the end of the article
}

\section{Methods}

Specimens were captured during a sampling program for decapod crustaceans, conducted from August 2008 to June 2013, on the subtidal rocky bottom at Couves Island $\left(23^{\circ} 25^{\prime} 15^{\prime \prime} \mathrm{S}-44^{\circ} 51^{\prime} 39^{\prime \prime} \mathrm{W}\right)$, in the Couves Archipelago, Ubatuba, Brazil. Samples were taken during daytime sessions of scuba diving, conducted by two divers. Each specimen was captured with the use of a hand net and immediately placed in an individual plastic bag, in order to ensure morphological integrity.

In the laboratory, shrimps were identified according to Rhyne \& Lin (2006) and Udekem d'Acoz (2000). Each specimen was measured for the length of the rostrum and carapace (CL), using a stereomicroscope equipped with an imaging and measurement tool (Zeiss Stemi DV 4, accuracy $0.01 \mathrm{~mm}$ ). The specimens were stored in $80 \%$ ethanol and deposited in the Scientific Collection of Carcinology, Laboratory of Marine Biology, University of Taubaté (LabBMar - UNITAU) and in the Carcinological Collection of the Museum of Zoology of the University of São Paulo (MZUSP 32641 and 32642). 


\section{Results}

Lysmata ankeri Rhyne \& Lin, 2006 (Fig. 1a)

Material examined: 17 specimens, size range: 3.6 10.3 mm CL - MZUSP-32641; coll. D. F. R. Alves.

Distribution: Western Atlantic - Southeastern U.S.A. (Florida), Haiti, Venezuela, Panama, Surinam, French Guyana and Brazil (Bahia to Rio de Janeiro and Santa Catarina) (Rhyne \& Lin 2006; Giraldes \& Freire, 2015; this study).

Remarks: Individuals were observed inhabiting crevices and natural burrows formed by rocks from 5 to about $15 \mathrm{~m}$ depth. Apparently solitary individuals and in small (fewer than 10 individuals) to large groups (over 30 individuals) were observed. The present material agrees with the description provided by Rhyne \& Lin (2006): rostrum mostly straight, reaching usually to middle, rarely past the end of third segment of antennular peduncle (Fig. 2a); the presence of the rostrum with 6-7 dorsal teeth (rarely five) and 3-6 ventral teeth (predominantly four) close to rostrum tip (Fig. 2b); second pereiopod with merus subdivided in 31 segments and carpus with 32-35 segments (Fig. 2c); and third-fifth pereiopods with dactylus biunguiculate, flexor margin with 3-4 spines (rarely two) (Fig. 2d).

This expansion of the variation limits of the number of teeth on the dorsal margin of the rostrum and the number of spines on the flexor margin of the dactyli in $L$. ankeri sampled in this study is discussed in Alves et al., 2015).

\section{Lysmata cf. intermedia (Kingsley, 1879) (Fig. 1b)}

Material examined: Two individuals, 5.4 and $6.2 \mathrm{~mm} \mathrm{CL}$ MZUSP-32642; coll. D. F. R. Alves; VII.2013.

Distribution: Western Atlantic - Florida Keys to Trinidad and Tobago, Curaçao and Brazil (Pernambuco, Sergipe, Bahia to São Paulo) (Ramos-Porto and Coelho, 1995; Christoffersen, 1998; Udekem d'Acoz, 2000; Almeida et al., 2007; Barros-Alves et al., in press; this study).

Remarks: The two specimens were found living under a large rocky plate, occurring syntopically with a large group (more than 30 individuals) of L. ankeri. The specimens examined were collected in 8 meters depth. The present material agrees with the description provided by Udekem d'Acoz (2000): the presence of the rostrum with 7 dorsal teeth: 3 in postrostral position and 4 in rostral position; 2 ventral teeth close to rostrum tip (Fig. 3a); antennular peduncle with stylocerite overreaching outer border of basal segment; accessory branch of outer antennular flagellum with 4 articles (Fig. 3b); third-fifth pereiopods with dactylus biunguiculate, flexor margin with four spines (Fig. 3c); and second pereiopod with merus subdivided in 17 segments (Fig. 3d). However, the carpus of second pereiopod is subdivided in 23 segments (Fig. 3d), agrees with the description provided by Almeida et al. (2007) and Santos et al. (2012). This variation found in morphology of carpus in the second pereiopod indicates that $L$. cf. intermedia is a species complex (Almeida et al., 2007; Anker et al., 2009; Santos et al., 2012).

\section{Discussion}

The current records of L.cf. intermedia and L. ankeri for the coast of São Paulo represent new distribution of these species, in addition to being the first record of $L$. cf. intermedia in waters of the Argentinian Province. The previous southern limit of occurrence of these shrimps was located off the northern coast of the State of Rio de Janeiro, near the Cabo Frio region (Ramos-Porto et al., 95/95; Rhyne \& Lin, 2006; Wirtz et al., 2009). According to Boschi (2000), the low water temperature that characterizes the region of Cabo Frio can limit the dispersion of thermophilic species southward, which makes this region a biological filter.

The absence of records of these species until the present is likely due to their cryptic habit, as well as to low collection efforts in the rocky subtidal of this region (e.g., Mantelatto et al., 2004a, 2004b; Cobo, 2006; Alves et al., 2011; Alves et al., 2012). However, the possibility remains that these shrimps crossed this biological filter through accidental transport, such as in ballast water, as previously recorded for other species of decapod crustaceans (e.g., Mantelatto \& Dias 1999; Alves et al., 2006; Tavares, 2011).

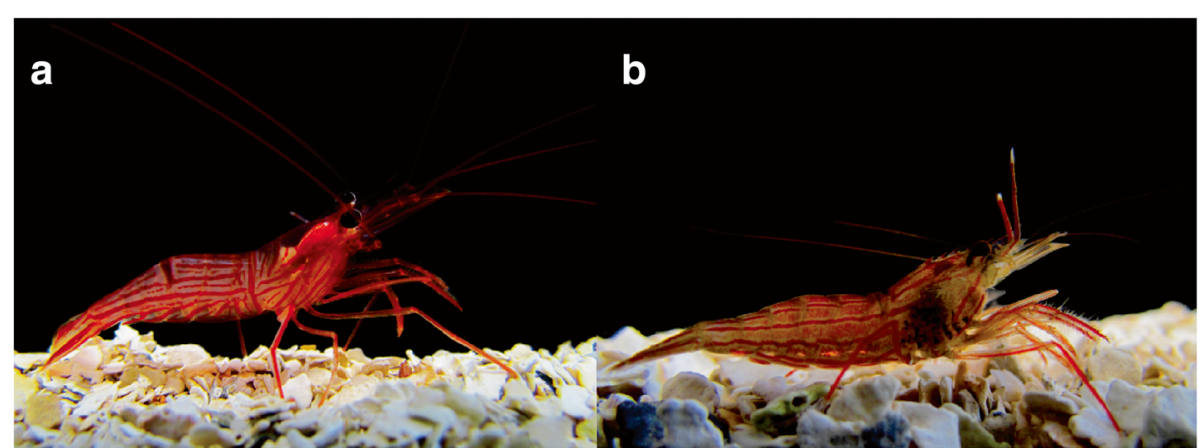

Fig. 1 Lateral view of Lysmata ankeri a and Lysmata cf. intermedia b captured on the subtidal rocky bottom at Couves Island, Ubatuba, Brazil. (Photo: Alves, DFR) 


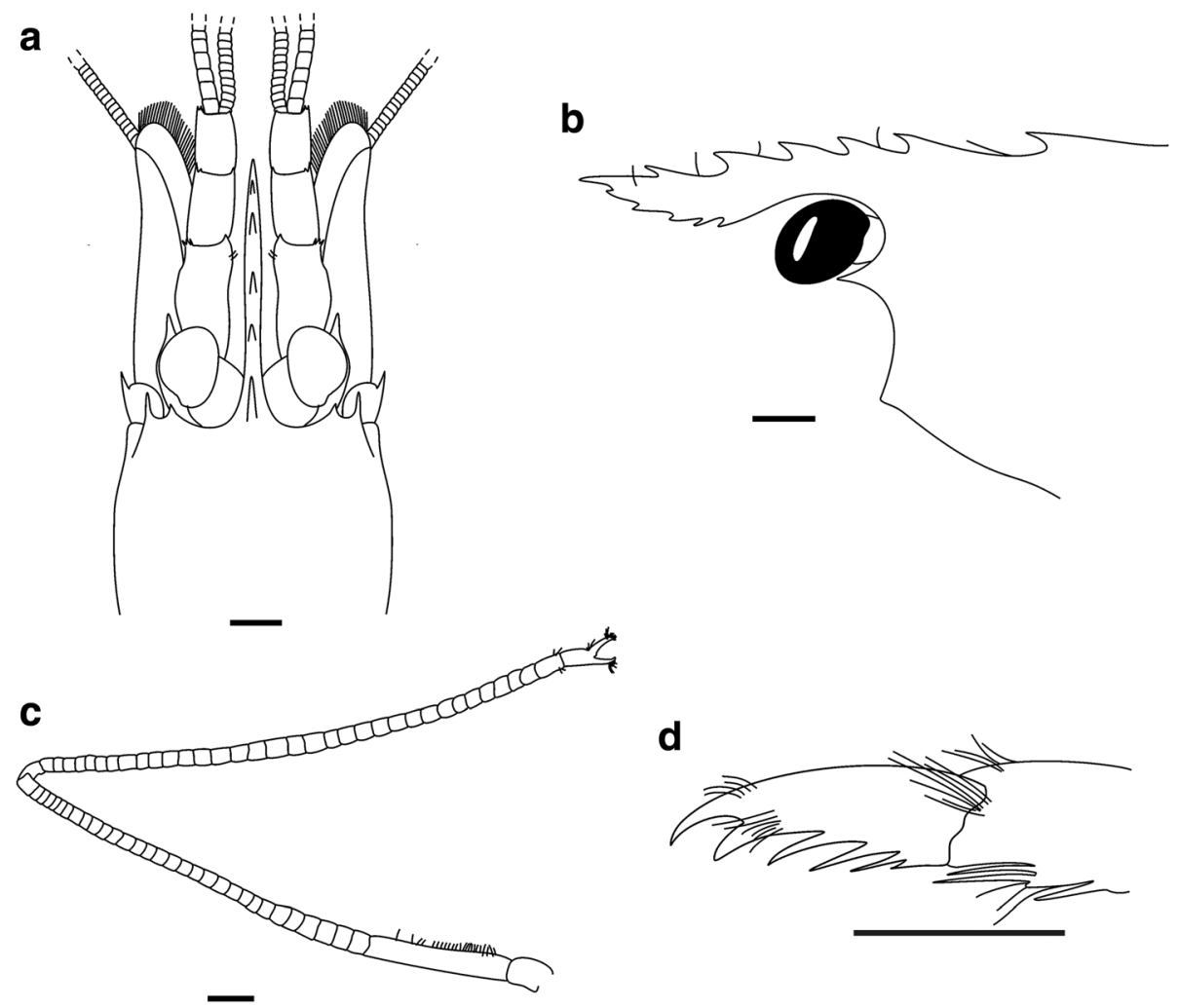

Fig. 2 Lysmata ankeri Rhyne \& Lin, 2006. a Anterior region and cephalic appendages, dorsal view; b Anterior region, lateral view; c right second pereiopod; d dactylus of right fifth pereiopod. Scale bars $=1.0 \mathrm{~mm}$

\section{a}
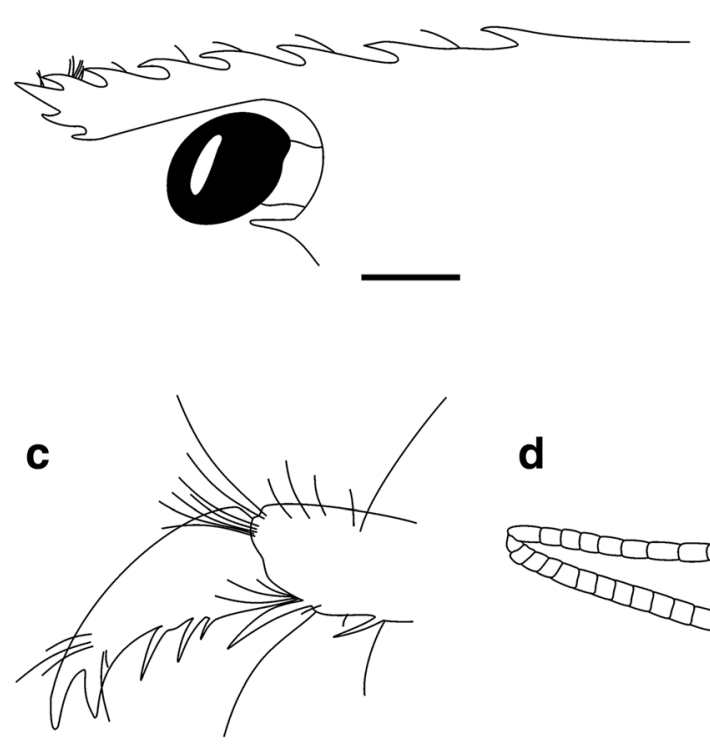

b
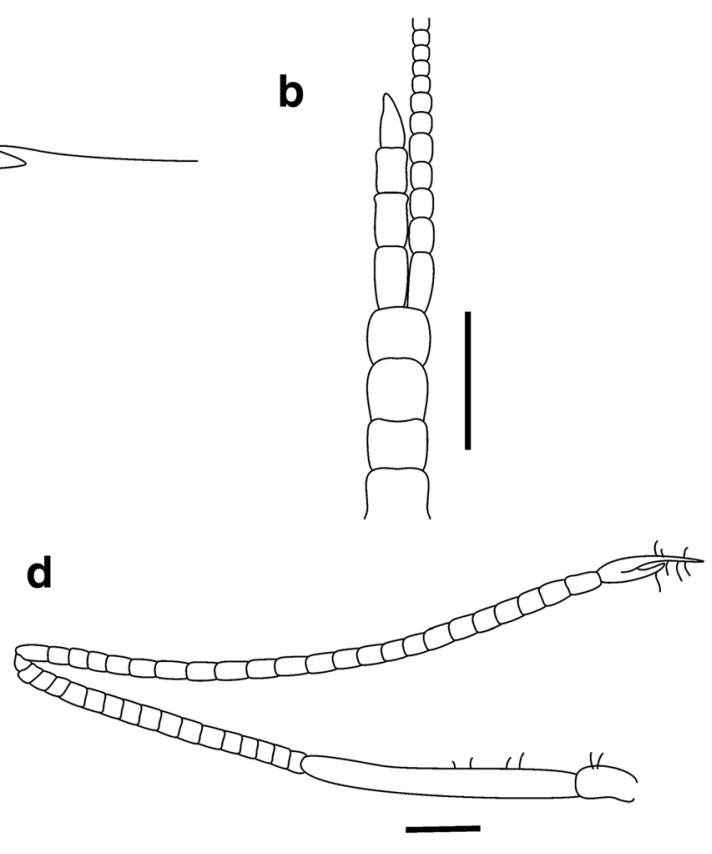

Fig. 3 Lysmata cf. intermedia (Kingsley, 1879). a Anterior region, lateral view; b right accessory branch of outer antennular flagellum; c dactylus of right fifth pereiopod; $\mathbf{d}$ right second pereiopod. Scale bars $=0.5 \mathrm{~mm}$ 


\section{Acknowledgements}

The authors are indebted to Dr. Janet W. Reid for her help with the English language. All sampling in this study has been conducted in compliance with applicable state and federal laws (IBAMA/ICMBio/SISBIO \#16101-1, 16101-2).

\section{Availability of supporting data}

The dataset supporting the conclusions of this article is included in the text, photographs and drawings of the article. The specimens were deposited in the Scientific Collection of Carcinology, Laboratory of Marine Biology, University of Taubaté (LabBMar - UNITAU) and in the Carcinological Collection of the Museum of Zoology of the University of São Paulo (MZUSP 32641 and 32642).

\section{Authors' contributions}

DFRA and VJC collected the data; DFRA identified the specimens; SPBA made the drawings; SPBA, DFRA and GLH wrote the manuscript; VJC participated in design and coordination of the manuscript. All authors have read and approved the final manuscript.

\section{Competing interests}

The authors declare that they have no competing interests.

\section{Author details}

${ }^{1}$ Universidade Federal de Sergipe - UFS, Laboratório de Carcinologia, São Cristóvão, Sergipe, Brazil. ²Universidade de Taubaté - UNITAU, Laboratório de Biologia Marinha, LabBMar, Instituto de Biociências, Taubaté, São Paulo, Brazil.

\section{Received: 23 May 2016 Accepted: 3 June 2016}

\section{Published online: 08 July 2016}

\section{References}

Almeida AO, Guerrazzi MC, Coelho PA. Stomatopod and decapod crustaceans from Camumu Bay, state of Bahia, Brazil. Zootaxa. 2007;1553:1-45.

Alves DFR, Barros-Alves SP, Hirose GL, Cobo VJ. Morphological remarks on the peppermint shrimp Lysmata ankeri (Decapoda, Hippolytidae): implications for species identification of the L. wurdemanni complex. Nauplius. 2015;23(1):53-8.

Alves DFR, Cobo VJ, Melo GAS. Extension of the geographical distribution of some brachyuran and porcellanid decapods (Crustacea) to the coast of the State of São Paulo, Brazil. Rev Bras Zool. 2006;23:1280-3.

Alves DFR, Barros-Alves SP, Cobo VJ. Composition and abundance of porcellanid crabs (Crustacea: Decapoda: Anomura) from rocky bottoms off Vitória Island, southeast coast of Brazil. Zoologia. 2011;28:214-8.

Alves DFR, Barros-Alves SP, Cobo VJ, Lima DJM, Fransozo A. Checklist of the brachyuran crabs (Crustacea: Decapoda) in the rocky subtidal of Vitória Archipelago, southeast coast of Brazil. Check List. 2012:8:940-50.

Anker A, Baeza JA, De Grave S. A new species of Lysmata (Crustacea: Decapoda: Hippolytidae) from the Pacific coast of Panama, with observations of its reproductive biology. Zool Stud. 2009;48:682-92.

Baeza JA. Molecular phylogeny of broken-back shrimps (genus Lysmata and allies): A test of the 'Tomlinson-Ghiselin' hypothesis explaining the evolution of hermaphroditism. Mol Phylogenet Evol. 2013;69:46-62.

Baeza JA, Anker A. Lysmata hochi n. sp., a new hermaphroditic shrimp from the southwestern Caribbean Sea (Caridea: Hippolytidae). J Crust Biol. 2008;28:148-55.

Barros-Alves S.P., Alves D.F.R., Silva S.L.R., Guimarães C.R.P. and Hirose G.L. (in press) New records of decapod crustaceans from the coast of Sergipe state, Brazil. Check List

Boschi EE. Species of Decapod Crustaceans and their distribution in the American marine zoogeographic provinces. Revista de Investigación y Desarrollo Pesquero. 2000;13:7-136.

Chace Jr FA. The shrimps of the Smithsonian-Bredin Caribbean Expeditions with a summary of the West Indian shallow-water species (Crustacea: Decapoda: Natantia). Smithson Contrib Zool. 1972;98:1-179.

Chace Jr FA. The Caridean Shrimps (Crustacea: Decapoda) of the Albatross Philippine Expedition, 1907-1910, Part 7: Families Atyidae, Eugonatonotidae, Rhynchocinetidae, Bathypalaemonellidae, Processidae and Hippolytidae. Smithson Contrib Zool. 1997;587:1-106

Christoffersen ML. Malacostraca. Eucarida. Caridea. Crangonoidea and Alpheoidea (Except Glyphocrangonidae and Crangonidae). In: Young PS, editor. Catalogue of Crustacea of Brazil. Rio de Janeiro: Museu Nacional; 1998. p. 351-72.

Cobo VJ. Population biology of the spider crab, Mithraculus forceps (A. Milne-Edwards, 1875) (Majidae, Mithracinae) on the southeastern Brazilian coast. Crustaceana. 2006;78:1079-10879.
De Grave S, Fransen CHJM. Carideorum catalogus: the recent species of the Dendrobranchiate, Stenopodidean, Procarididean and Caridean shrimps (Crustacea: Decapoda). Zool Med Leiden. 2011;85:195-588.

Giraldes BW, Freire AS. Extending the southern range of four shrimps (Crustacea: Decapoda: Stenopodidae, Hippolytidae and Alpheidae) in southwestern Atlantic $\left(27^{\circ} \mathrm{S}\right)$ and confirming the presence of Mediterranean Stenopus spinosus Risso, 1827 in Brazil. Zootaxa. 2015;3972(3):419-31.

Kingsley JS. Notes on the North American Caridea in the Museum of the Peabody Academy of Science at Salem. Mass Proc Acad Sci Philadelphia. 1879;89-98.

Laubenheimer $\mathrm{H}$, Rhyne AL. Lysmata raulii, a new species of peppermint shrimp, (Decapoda: Hippolytidae) from the southwestern Atlantic. Zootaxa. 2010; 2372:298-304.

Mantelatto FLM, Dias LL. Extension of the known distribution of Charybdis hellerii (A. Milne-Edwards, 1867) (Decapoda, Portunidae) along the western tropical South Atlantic. Crustaceana. 1999;72:617-20.

Mantelatto FLM, Biagi R, Faria FCR, Meireles AL, Melo GAS. Checklist on brachyuran fauna (Decapoda) from infralittoral rocky/sandy bottom of Anchieta Island, São Paulo State, Brazil. Nauplius. 2004a;12:135-42.

Mantelatto FLM, Faria FCR, Garcia RG, Melo GAS. Majoid crabs community (Crustacea: Decapoda) from infralittoral rocky/sandy bottom of Anchieta Island, Ubatuba. Braz Arch Biol Technol. 2004b;47:273-9.

Ramos-Porto M, Coelho PA. Sinopse dos crustáceos decápodos brasileiros (família Pasiphaeidae). Trabalhos do Instituto Oceanográfico da Universidade Federal de Pernambuco. 1995;23:129-33.

Ramos-Porto M, Carvalho PVDBC, Botter-Carvalho ML. Registro de Lysmata intermedia (Kingsley, 1878) (Decapoda, Hippolytidae) no litoral Pernambuco. Trabalhos do Instituto Oceanográfico da Universidade Federal de Pernambuco. 1994/95;23:107-11.

Rhyne AL, Anker A. Lysmata rafa, a new species of peppermint shrimp (Crustacea, Caridea, Hippolytidae) from the subtropical western Atlantic. Helgol Mar Res. 2007;61:291-6.

Rhyne AL, Lin J. A western Atlantic peppermint shrimp complex: redescription of Lysmata wurdemanni (Gibbes), description of four new species and remarks on L. rathbunae Chace (Crustacea: Decapoda: Hippolytidae). Bull Mar Sci. 2006;79:165-204.

Santos PS, Soledade GO, Almeida AO. Decapod crustaceans on dead coral from reef areas on the coast of Bahia, Brazil. Nauplius. 2012;20(2):145-69.

Tavares M. Alien decapod crustaceans in the Southwestern Atlantic Ocean. In: Galil B, Clark PF, Carlton JT, editors. In the Wrong Place - Alien Marine Crustaceans: Distribution, Biology and Impacts. London: Springer Series in Invasion Ecology; 2011. p. 251-67.

Udekem d'Acoz C. Redescription of Lysmata intermedia (Kingsley, 1879) based on topotypical specimens, with remarks on Lysmata seticaudata (Risso 1816) (Decapoda, Caridea, Hippolytidae). Crustaceana. 2000;73:719-35.

Wicksten MK. A new species of Lysmata (Caridea, Hippolytidae) from the eastern Pacific. Crustaceana. 2002a;73:207-13.

Wicksten MK. The species of Lysmata (Caridea: Hippolytidae) from the eastern Pacific Ocean. Amphipacifica. 2002b;2:3-22.

Wirtz P, Melo G, De Grave S. Symbioses of decapod crustaceans along the coast of Espírito Santo, Brazil. Mar Biodivers Rec. 2009;2:1-9.

\section{Submit your next manuscript to BioMed Central and we will help you at every step:}

- We accept pre-submission inquiries

- Our selector tool helps you to find the most relevant journal

- We provide round the clock customer support

- Convenient online submission

- Thorough peer review

- Inclusion in PubMed and all major indexing services

- Maximum visibility for your research

Submit your manuscript at www.biomedcentral.com/submit 